\title{
Management of Damping off (Pythium sp.) in Radish by Different Isolates of Trichoderma spp.
}

\author{
Irshad Shaikh*, S. Simon, A.A. Lal, Yelleti Tejaswi and G. Grace Sushanthi \\ Department of Plant Pathology, Sam Higginbottom University of Agriculture Technology and \\ Sciences, Prayagraj- 211007 (U.P.), India \\ *Corresponding author
}

\begin{tabular}{|c|c|}
\hline & A B S T R A C T \\
\hline & \multirow{4}{*}{$\begin{array}{l}\text { The experiment was carried both in in vitro and in situ during } 2017-18 \text { at } \\
\text { Sam Higginbottom University of Agriculture Technology and Sciences, } \\
\text { Allahabad to evaluate the efficacy of Trichoderma isolates against Pythium } \\
\text { sp. Under in vitro condition the results revealed that Trichoderma sp. } \\
\text { (isolate 5) effectively inhibited the radial mycelial growth of Pythium sp. } \\
\text { (71.66\%). Under in situ conditions Trichoderma isolates were tested } \\
\text { against the damping off (Pythium sp.) disease of radish. Under in situ } \\
\text { condition application of Trichoderma asperellum (isolate 2) showed } \\
\text { maximum germination percentage }(87.77 \%) \text { in radish seeds. }\end{array}$} \\
\hline $\begin{array}{l}\text { Antagonism, } \\
\text { Biological control, } \\
\text { Pythium sp. and } \\
\text { Trichoderma } \\
\text { isolates }\end{array}$ & \\
\hline Article Info & \\
\hline $\begin{array}{l}\text { Accepted: } \\
\text { 22 July } 2019 \\
\text { Available Online: } \\
\text { 10 August } 2019\end{array}$ & \\
\hline
\end{tabular}

\section{Introduction}

Pythium spp. are worldwide in distribution that attack cuttings, seeds, seedlings and all stages of the various crops causing significant losses to them. Almost all greenhouse crops are susceptible to one or more species of Pythium. Of the different species of Pythium, $P$. aphanidermatum (Edson) Fitz. is reported from a large number of hosts. The most common means to check the disease caused by $P$. aphanidermatum in plants is by using fungicides. Frequent use of these chemicals leads to environmental pollution. The increasing awareness of fungicide -related hazards has emphasized the need of adopting biological methods as an alternative disease control method. Species of the genus Trichoderma are well documented fungal biocontrol agents. The antagonistic action of Trichoderma species against phytopathogenic fungi might be due to either by the secretion of extracellular hydrolytic enzymes or by the production of antibiotics. In view of the above, the present study was carried out to investigate the effective strain of Trichoderma species against $P$. aphanidermatum under the Allahabad Agroclimatic conditions.

The etymology of Trichoderma is taken from thrix (hair and derma) skin. Trichoderma is free living, asexually reproducing and 
filamentous fungi. It is an exceptionally good model of biocontrol agent as it is widely spread, easy to isolate and culture, multiply rapidly on many substrates, act as mycoparasite, strong opportunistic invaders, avirulent plant symbionts, competes for food and site, prolific producers of spores and powerful antibiotics, antifungal compounds, secondary metabolites and enzymes. These properties make these fungi ecologically very successful and are the reasons for their ubiquitousness. Several species of Trichoderma are used as biological control agents against soil borne plant pathogenic fungi. However, commercialization of Trichoderma for its utility in field crops could not be achieved successfully. A series of a biotic and biotic parameters have on influence of the biocontrol efficacy of Trichoderma.

\section{Materials and Methods}

Antagonistic effect of different isolates of Trichoderma were evaluated by dual culture technique for their antagonism against Pythium sp. Six isolates of Trichoderma spp. were collected from the different locations. Trichoderma spp. were cultured in the medium specific for Trichoderma and maintained on PDA medium for further studies. From 7 days old culture grown on PDA, mycelial disc (5 $\mathrm{mm}$ dia.) of the test organism was cut aseptically from the periphery of the actively growing fungus culture plate and placed opposite to each other approximately $60 \mathrm{~mm}$ apart onto PDA contained in the Petri Plates, replicated thrice. Observations on radial growth were recorded till the complete coverage of plates with pathogen. The per cent growth inhibition of the fungus was worked (Morton and Stroube, 1955).

Evaluation of Trichoderma strains against damping off in radish:
The damping off mainly being soil borne, the primary infections are needed to be controlled with bio-control agents. For testing biocontrol agents in the infested soil the greenhouse experiment was planned in Completely Randomized Design with 3 replications and 7 treatments. For preparation of inoculum in the form of infested soil the normal surface soil was collected randomly from the field, it was thoroughly mixed, sieved through screen. Then the soil was sterilized with 0.2 per cent formaldehyde and the sterilized soil was covered with black plastic. Then the sterilized soil was left undisturbed for 5 days.

Simultaneously Farm Yard Manure (FYM) was also sterilized with 0.2 per cent formaldehyde. Then the pathogen was mixed with FYM and it was left undisturbed for 7 days for its growth (Rahman and Bhattiprolu, 2005).

Now the plastic containers with drainage hole of $3 \mathrm{~cm}$ diameter at the bottom were filled with sterilized amended soil of $0.5 \mathrm{~kg}$ per container. Along with the soil, $10 \mathrm{~g}$ of FYM mixed with pathogen was added in each container. The absolute control without seed treatment, soil inoculation was also maintained (Chandar et al., 2016).

\section{Seed treatment}

Bio-control agents were used as seed treatment for evaluation against damping off of tomato and radish. Green house experiment was conducted in CRD with 3 replications and 7 treatments and seeds were smeared with bio- agents one night before sowing. Bioagent culture from 1 Petri plate $(90 \mathrm{~mm}$ diam.) was used for smearing 48 seeds (Zagade et al., 2012).Treated seeds were sown in the infested soil in plastic containers. Observations on germination were recorded after 10 days of sowing. 


\section{Results and Discussion}

Trichoderma asperellum (isolates 1), $T$. asperellum (isolates 2), Trichoderma longibrachiatum (isolate 3), T. harzianum (isolate 4), Trichoderma sp. (isolate 5) and $T$. asperellum (isolates 6) were isolated from four states of India (Chhattisgarh, Uttar Pradesh, Andhra Pradesh and Maharashtra). Trichoderma sp. (isolate 5) recorded maximum \% inhibition of mycelial growth against Pythium sp. (71.66 \%) Johnson, 1957; Bandhyopadhyay et al., 2003; Kolte and Singh et al., 2008) (Plate 1).

Trichoderma isolates inhibited growth of pathogen. The probable reason for such finding may be that Trichoderma secreted mycoparasitism, antibiosis involving enzymes and secondary metabolites and the detection, attachment, direct penetration, and secretion of fungitoxic enzymes which leads to death of pathogen (Gurha, 2011; Kamlesh and Gurjar, 2002; Singh et al., 2011; Choudhary et al., 2016).
Trichoderma asperellum (isolate 2) recorded maximum germination \% in radish against Pythium sp. (Damping off) in radish (Plate 2). The present findings are of one season under Allahabad agro - climatic conditions as such to validate the findings more such trials should be taken up in future (Singh et al., 2008; Debnath et al., 2010).

The Trichoderma asperellum (isolate 2) a native isolate from the rhizospheric soil of black gram growing at the Central Research Field, SHUATS, Allahabad area was found to significantly, the most effective isolate against damping off caused by Pythium sp. in radish. The probable reason for such findings may be due to $T$. asperellum (isolate 2) being a native isolate was able to grow better than other isolates collected from different locations. The environmental factors such as temperature and relative humidity play a key role on the antagonistic effect of bio agents against the pathogens. Similar findings have also been reported by Raju and Murthy, 2000; Gupta et al., 2006; Anand and Reddy, 2009; Ambuse et al., 2012 and Debnath et al., 2010.

Table.1 Bio - efficacy of isolates against Pythium sp.

\begin{tabular}{|l|c|c|}
\hline \multicolumn{1}{|c|}{ Trichoderma isolates } & \multicolumn{2}{c|}{ Pythium sp. } \\
\cline { 2 - 3 } & $\begin{array}{c}\text { Per cent growth } \\
\text { inhibition }\end{array}$ & $\begin{array}{c}\text { Germination (\%) 10 } \\
\text { DAS }\end{array}$ \\
\hline Control & 0.00 & 37.77 \\
\hline Trichoderma asperellum (isolate 1) & 71.38 & 72.22 \\
\hline Trichoderma asperellum (isolate 2) & 69.72 & 87.77 \\
\hline Trichoderma longibrachiatum (isolate 3) & 66.38 & 54.44 \\
\hline Trichoderma harzianum (isolate 4) & 70.00 & 61.11 \\
\hline Trichoderma sp. (isolate 5) & 71.66 & 71.11 \\
\hline Trichoderma asperellum (isolate 6) & 65.83 & 77.77 \\
\hline C.D. (at 0.05\%) & 1.38 & 2.68 \\
\hline
\end{tabular}


Plate.1 Antagonistic efficacy of Trichoderma isolates against Pythium sp. (per cent growth inhibition) at 5 DAI A - Trichoderma asperellum (isolate 1), B - Trichoderma asperellum (isolate 2), C - Trichoderma longibrachiatum (isolate 3), D - Trichoderma harzianum (isolate 4), E - Trichoderma sp. (isolate 5), F - Trichoderma asperellum (isolate 6), G - Control

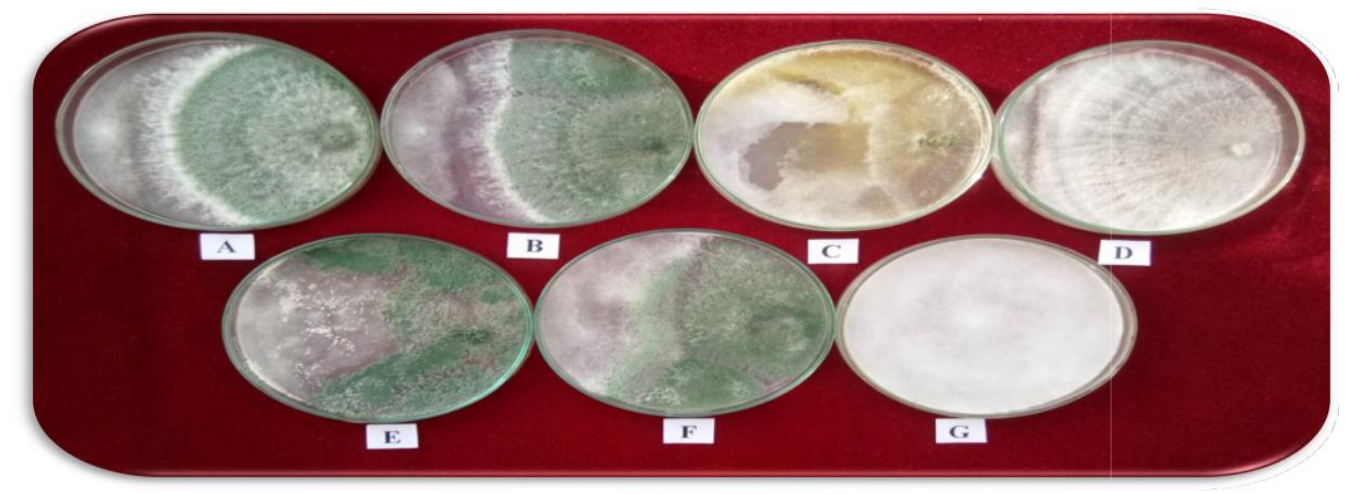

Plate: 2 Efficacy of Trichoderma isolates against damping off (Pythium sp.) in radish

A - Trichoderma asperellum (isolate 1),

C - Trichoderma longibrachiatum (isolate 3), E

- Trichoderma sp. (isolate 5), $\mathrm{G}$ - Control
B - Trichoderma asperellum (isolate 2),

D - Trichoderma harzianum (isolate 4),

F - Trichoderma asperellum (isolate 6),

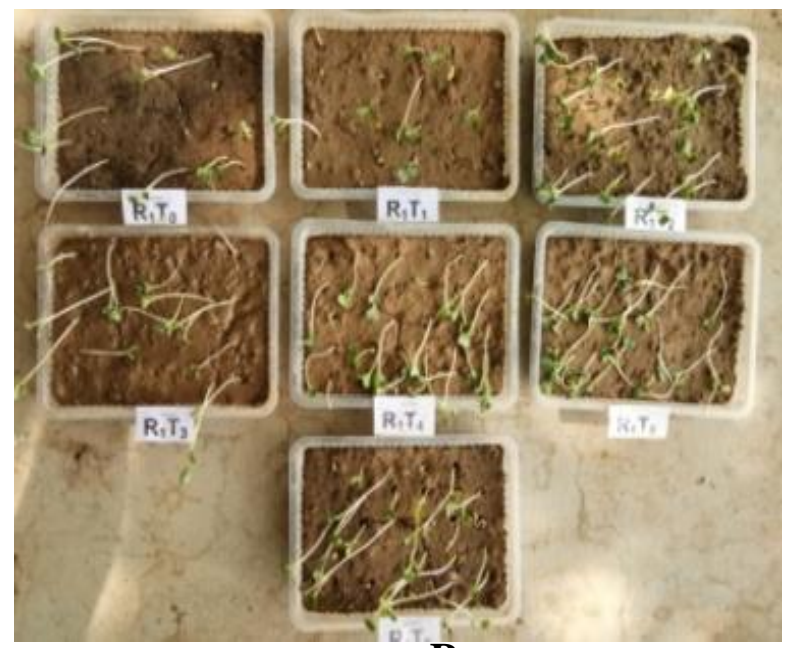

$\mathbf{R}_{1}$

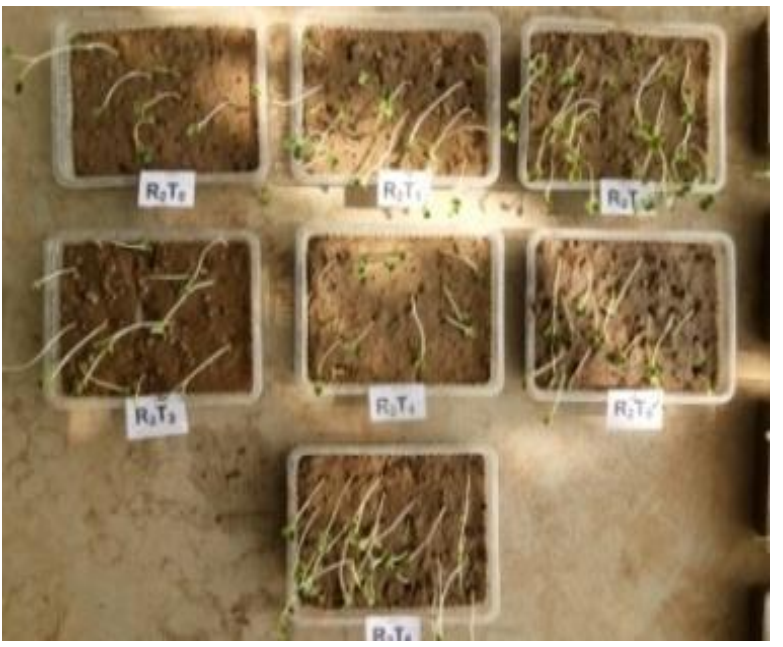

$\mathbf{R}_{2}$

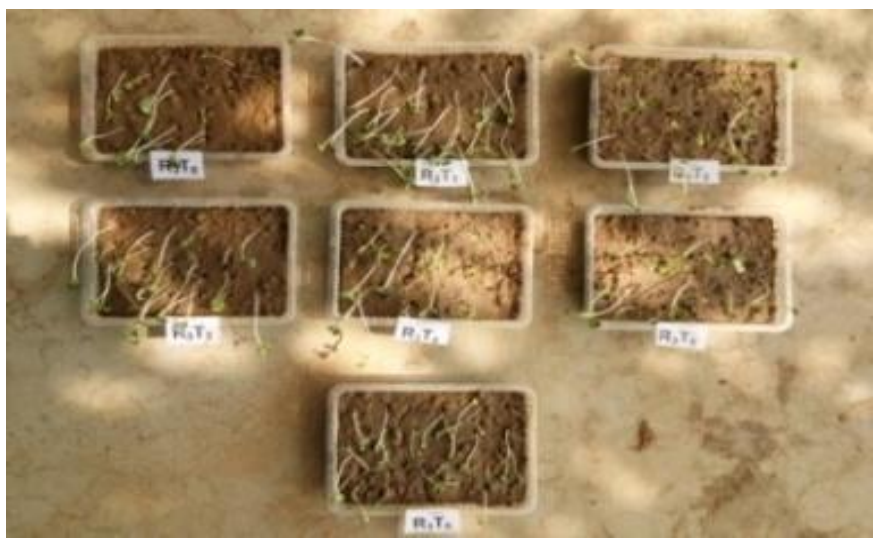

$\mathbf{R}_{\mathbf{3}}$ 


\section{References}

Ambuse, M. G., Chatage, V. S. and Bhale, U. N. 2012. Influence of Trichoderma spp. against Alternaria tenuissima inciting leaf spot of Rumex acetosa L. Bioscience Discovery, 03(2):259-262.

Anand, S. and Reddy, J. 2009. Biocontrol potential of Trichoderma sp. against plant pathogens.

Bandhyopadhyay, S., N.D. Sharma and Dutta, S. 2003. Screening of potential Trichoderma strains against major pest pathogens. Annals of Plant protection Sciences. 16: 433-437.

Chandar, K., S. Gangopadhyay and Godara, S. L. 2016. Eco-friendly management of wilt caused by Fusarium oxysporum f.sp. ciceri in chickpea. Legume Research - An International Journal. 39(1): 129-134.

Choudhary, A., A.A. Lal, S. Simon and Bana, P. 2016. In vitro bio-efficacy of plant extract and bioagents against Fusarium oxysporum $\mathrm{f}$. sp. lycopersici L. Annals of Plant protection Sciences. 24: 422-443.

Debnath, A., S. Bandyopadhyay and Dutta, S. 2010. Bio-control options for management of rhizome rot and wilt disease complex of ginger in Terai agro -ecological region. Annals of Plant protection Sciences. 18: 193196.

Gupta, S. B., K.S. Thakur, K. Tedia and Singh, A. K. 2006. Influence of Trichoderma viride on performance of chick pea in wilt complex area. Annals of Plant protection Sciences. 14: 120-124.

Gurha, S.N. 2001. Effect of some Trichoderma spp. on growth of different isolates of Fusarium oxysporum. Annals of Plant protection Sciences. 9: 332-334.

International Journal of Agricultural Science, 2:30-39.

Johnson, L. A. 1957. Effect of antibodies on the number of bacteria and fungi isolated from soil by dilution plate method. Phytopathology. 47:21-22.

Kamlesh, M. and Gurjar, R. B. S. 2002. Evaluation of different fungal antagonistic, plant extracts and oilcakes against Rhizoctonia solani causing stem rot of chilli seedlings. Annals of Plant protection Sciences. 10: 319-322.

Kolte, V.S. and Raut, S. P. 2007. Efficacy of Trichoderma spp. against Sclerotium rolfsii inciting collar rot of orchids. Annals of Plant protection Sciences. 15: 516-517.

Morton, D. T. and Stroube, N. H. 1955. Antagonistic and stimulatory effects of microorganism upon Sclerotium rolfsii. Phytopathology. 45:419- 420.

Rahman, M. A. and Bhattiprolu, S. L. 2005. Efficacy of fungicides and mycorrhizal fungi for the control of damping-off disease in nurseries of tomato, chilli and brinjal crops. Karnataka Journal of Agricultural Sciences. 18(2): 401-406.

Raju, M. R. B. and Murthy, K. V. M. K. 2000. Efficacy of Trichoderma spp. In the management of collar rot of groundnut caused by Aspergillus niger, Van Tieghem. Indian Journal Plant Protection, 28:197-199.

Singh, A.K., A.K. Singh, M. Singh, J. Singh and Singh, S. B. 2008. Bio-intensive management of soil -borne disease of sunflower. Annals of Plant protection Sciences. 16: 433-437.

Singh, L., R.K. Bagri, B.B.L. Thakore, J. Singh and P. Singh 2011. Effect of pH sources on production of enzyme by Fusarium oxysporum f. sp. pisi. Annals of Plant protection Sciences. 19: 388-391.

Zagade, S.N., G.D. Deshpande, D.B. Gawade, A.A. Atnoorkar and Pawar, S. V. 2012. Biocontrol agents and fungicides for management of damping off in chilli. World Journal of Agricultural Sciences. 8(6): 590597.

\section{How to cite this article:}

Irshad Shaikh, S. Simon, A.A. Lal., Yelleti Tejaswi and Grace Sushanthi, G. 2019. Management of Damping off (Pythium sp.) in Radish by Different Isolates of Trichoderma spp.. Int.J.Curr.Microbiol.App.Sci. 8(08): 2511-2515.

doi: https://doi.org/10.20546/ijcmas.2019.808.292 